\title{
Pengaruh Konsentrasi Pupuk Organik Cair Terhadap Pertumbuhan dan Hasil Dua Varietas Mentimun (Cucumis sativus L.)
}

\author{
Effect of Liquid Organic Fertilizer Concentration on Growth and Yield \\ of Two Cucumber Varieties (Cucumis sativus L.) \\ Tri Yanto, Jumini ${ }^{1}$, Rika Husna ${ }^{1^{*}}$ \\ *Corresponding author: jumini_ali@unsyiah.ac.id
}

\begin{abstract}
Abstrak. Percobaan memiliki tujuan untuk mengetahui pengaruh konsentrasi pupuk organik cair dan varietas mentimun serta interaksi antara keduanya pada pertumbuhan dan hasil mentimun. Percobaan ini dilakukan di Kebun Percobaan Fakultas Pertanian Universitas Syiah Kuala, Banda Aceh. Jenis tanah Aluvial dengan ketinggian tempat $\pm 0,80$ mdpl, yang dilaksanakan dari bulan September sampai November 2019 . Rancangan yang digunakan adalah RAK Faktorial dengan 3 ulangan. Terdapat dua faktor yang diamati yakni konsentrasi pupuk organik cair yang terdiri dari lima perlakuan yaitu $0,75,150,225$ dan $300 \mathrm{ml} \mathrm{L}^{-1}$ air, dan varietas mentimun yang terdiri dari dua perlakuan yakni Hercules dan Mercy. Hasil yang diperoleh dari percobaan ini pada perlakuan konsentrasi pupuk organic cair tidak memberikan memberikan pengaruh yang nyata pada seluruh parameter pengamatan. Perlakuan varietas memberikan pengaruh yang sangat nyata pada panjang buah dan diameter buah, serta memberikan pengaruh yang nyata pada berat per buah. Panjang buah dan berat per buah terbaik dijumpai pada varietas Hercules sedangkan diameter buah terbaik dijumpai pada varietas Mercy. Terdapat interaksi yang nyata antara perlakuan konsentrasi pupuk organik cair dengan varietas mentimun pada panjang buah. Panjang buah terbaik terdapat pada kombinasi konsentrasi pupuk organik cair $150 \mathrm{ml} \mathrm{L}^{-1}$ air dengan varietas Hercules.
\end{abstract}

Kata Kunci: Mentimun, pupuk organik cair, varietas

\begin{abstract}
This research aims to determine the effect of the concentration of liquid organic fertilizer and cucumber varieties and the interaction between the two on the growth and yield of cucumber plants. This research was conducted in the Experimental Garden of the Faculty of Agriculture, Syiah Kuala University, Banda Aceh. The type of soil used is Alluvial with a height of \pm 0.80 above sea level, which was conducted from September to November 2019. This research used a Factorial RAK with 3 replications. There are two factors that are researched, namely the concentration of liquid organic fertilizer consisting of five levels, namely $0,75,150,225$ and $300 \mathrm{ml} \mathrm{L}^{-1}$ water, and cucumber varieties consisting of two levels, namely Hercules and Mercy. The results showed that the treatment of liquid organic fertilizer concentration did not significantly affect all observed parameters. The treatment of varieties had a very significant effect on fruit length and diameter, and also had a significant effect on weight per fruit. The best fruit length and weight per fruit were found in the Hercules variety while the best fruit diameter was found in the Mercy variety. There is a real interaction between the treatment of liquid organic fertilizer concentration with cucumber varieties on fruit length. The best fruit length is found in a combination of a concentration of liquid organic fertilizer 150 $\mathrm{ml} \mathrm{L}^{-1}$ of water with a variety of Hercules
\end{abstract}

Keywords: Cucumbers, liquid organic fertilizers, varieties

\section{PENDAHULUAN}

Di Indonesia peluang untuk membudidayakan mentimun sangat menjanjikan karena buah mentimun sangat diminati oleh banyak masyarakat. Komoditas ini memiliki permintaan yang berjumlah besar serta kontinu. Kebutuhan komoditas ini akan selalu mengalami peningkatan seiring bertambahnya masyarakat serta meningkatnya taraf kehidupan, ilmu pengetahuan dan sadar akan pentingnya kebutuhan gizi (Wijoyo, 2012). Namun dari tahun 2010 hingga 2015 hasil panen buah mentimun selalu merosot. Tahun 2010 hasil produksi buah mentimun secara nasional sebanyak 547.141 ton, tahun 2011 
sebanyak 521.535 ton, tahun 2012 sebanyak 511.525 ton, tahun 2013 sebanyak 491.636 ton, tahun 2014 sebanyak 477.989 ton, dan tahun 2015 sebanyak 447.696 ton (Badan Pusat Statistik, 2017). Pada tahun 2018 pengembangan budidaya mentimun dari berbagai jenis sayuran komersial yang dihasilkan di Indonesia menjadi urutan ke 12 setelah bawang merah, kubis, cabai rawit, kentang, cabai besar, tomat, sawi, wortel, bawang daun, terung dan labu siam (Badan Pusat Statistik, 2019). Untuk meningkatkan produksi mentimun maka perlu dilakukan perbaikan kesuburan tanah yaitu dengan pemupukan.

Pemupukan adalah salah satu usaha untuk meningkatkan kesuburan tanah yang berfungsi untuk menyediakan hara yang optimum sehingga dapat menunjang pertumbuhan tanaman yang dapat meningkatkan hasil panennya (Dermiyati, 2015). Pupuk yang tidak menimbulkan kerusakan bagi tanah meskipun digunakan secara terus menerus adalah pupuk organik karena berfungsi membenahi karakter biologi, fisika dan kimia tanah. Menurut bentuk, pupuk organik bisa dibedakan dalam 2 jenis yakni pupuk organik cair dan padat. Menurut Rostini et al (2016) pupuk organik cair adalah larutan hasil fermentasi yang sumbernya dari bahan-bahan organik seperti kotoran hewan, sisa tanaman dan limbah rumah tangga. Pardosi et al (2014) memaparkan bahwasanya pupuk berwujud cair memiliki kelebihan yaitu kandungan haranya akan segera muncul serta langsung terserap oleh perakaran tanaman. Pupuk berwujud cair selain diaplikasikan dengan menyiramkan ke tanah, juga bisa disemprotkan langsung ke seluruh bagian tanaman. Berdasarkan penelitian yang telah dilakukan Duaja (2012) hasil yang diperoleh pada tanaman selada keriting menunjukkan bahwa pada perlakuan pupuk cair kotoran ayam lebih baik dibanding urea, yakni untuk parameter jumlah daun, tinggi dan bobot segar tanaman.

Berdasarkan penelitian Rambitan dan Mirna (2015) pupuk cair kulit pisang memperlihatkan hasil yang berpengaruh pada parameter tinggi, jumlah daun dan bobot basah polong kacang tanah. Adapun hasil terbaik ditunjukkan pada perlakuan pupuk organik cair berkonsentrasi $250 \mathrm{ml} \mathrm{L}^{-1}$ air karena mempunyai kandungan hara paling tinggi diantara perlakuan yang lain.

Selain pemupukan, produksi mentimun juga dipengaruhi oleh varietas mentimun yang dibudidayakan. Menurut Rukmana (1994) jenis mentimun hibrida sangat tergantung pada pemupukan. Syarif (2010) menyatakan bahwa tiap-tiap varietas mempunyai karakter gen yang berbeda-beda, sehingga akan memperoleh hasil produksi dan karakter buah yang berbeda pula. Pernyataan tersebut sejalan dengan pendapat Idris (2004) bahwa budidaya mentimun menggunakan varietas hibrida merupakan upaya agar memperoleh produksi dan kualitas lebih tinggi. Mentimun Hibrida mampu mengahasilkan produksi yang lebih baik dengan kualitas hasil dan keseragaman yang tinggi.

\section{METODE PENELITIAN}

\section{Waktu dan Tempat}

Penelitian ini telah dilakukan di Kebun Porcobaan Fakultas Pertanian Universitas Syiah Kuala, Kecamatan Darussalam, Kota Banda Aceh, yang dilaksanakan dari bulan September sampai November 2019. Jenis tanah Entisol dengan ketinggian tempat $\pm 0,80$ mdpl.

\section{Alat dan Bahan}

Alat yang digunakan dalam penelitian ini yaitu parang, cangkul, garu, pisau, traktor, meteran, jangka sorong, blender, gembor, ember, drum plastik berukuran $100 \mathrm{~L}$, knapsack sprayer, trai semai, kayu ajir, tali rafia, gelas ukur, papan nama, timbangan 
digital, timbangan duduk dan kertas label. Sedangkan bahan yang digunakan dalam penelitian ini adalah $576 \mathrm{~g}$ urea, $360 \mathrm{~g}$ SP-36, $360 \mathrm{~g} \mathrm{KCl}$, inseksitisida Decis $25 \mathrm{EC}$, fungisida Dithane M-45 80 WP, benih mentimun varietas Hercules F1 dan varietas Mercy F1 masing-masing sebanyak 460 benih, serta bahan-bahan untuk membuat pupuk organik cair yaitu $15 \mathrm{~kg}$ kotoran ayam petelur, $15 \mathrm{~kg}$ kulit pisang kepok, 1 liter EM4, 1 liter molase dan 50 liter air.

\section{Metode Penelitian}

Penelitian ini menggunakan Rancangan Acak Kelompok (RAK) pola faktorial dengan 3 ulangan. Faktor pertama adalah konsentrasi pupuk organik cair $(\mathrm{K})$ yang terdiri dari lima taraf yaitu $\mathrm{K}_{0}(0 \mathrm{ml} \mathrm{L}-1$ air $), \mathrm{K}_{1}\left(75 \mathrm{ml} \mathrm{L}^{-1}\right.$ air $), \mathrm{K}_{2}\left(150 \mathrm{ml} \mathrm{L}^{-1}\right.$ air $), \mathrm{K}_{3}\left(225 \mathrm{ml} \mathrm{L}^{-1}\right.$ air) dan $\mathrm{K}_{4}$ (300 $\mathrm{ml} \mathrm{L}^{-1}$ air). Faktor kedua adalah varietas memtimun (V) yang terdiri dari dua taraf yaitu $\mathrm{V}_{1}$ (Varietas Hercules) dan $\mathrm{V}_{2}$ (Varietas Mercy). Dengan demikian terdapat 10 kombinasi perlakuan. Masing-masing kombinasi perlakuan diulang sebanyak tiga kali, sehingga terdapat 30 plot percobaan. Data hasil percobaan dianalisis menggunakan Anova. Jika hasil uji $\mathrm{F}$ menunjukkan berpengaruh nyata $(\alpha=5 \%)$, kemudian dilanjutkan dengan Uji DNMRT taraf 5\%.

\section{Pelaksanaan Penelitian}

\section{Pembuatan Pupuk Organik Cair}

Pupuk organik cair dibuat dengan menyediakan $15 \mathrm{~kg}$ kotoran ayam dari peternakan ayam petelur, $15 \mathrm{~kg}$ kulit pisang kepok yang berwarna kuning dan masih segar, satu liter EM4, satu liter molase dan drum plastik ukuran 100 liter yang diisi air sebanyak 50 liter. Cara pembuatannya yaitu kulit pisang kepok dipotong kecil-kecil kemudian diblender dengan menggunakan sebagian air dari 50 liter air yang telah disediakan tersebut. Setelah selesai diblender kulit pisang kepok dimasukkan ke dalam drum plastik. Kemudian dimasukkan juga $15 \mathrm{~kg}$ kotoran ayam, satu liter EM4, dan satu liter molase ke dalam drum plastik, lalu diaduk-aduk dan difermentasi dalam keadaan yang tertutup. Setiap hari tutup drum plastik tersebut dibuka selama lima menit agar mengeluarkan gas dari dalam drum plastik tersebut, kemudian diaduk-aduk. Adapun ciri-ciri pupuk organik cair yang telah berhasil ditandai dengan bau seperti tapai yaitu ketika telah difermentasi selama 60 hari. Jika pupuk organik cair berbau busuk dan menyengat maka dinyatakan belum berhasil.

\section{Persiapan Lahan}

Lahan diolah dengan menggunakan traktor, lalu digemburkan dengan mencangkul sampai tanah menjadi gembur dan rata. Kemudian dibuat plot percobaan dengan luas $1 \mathrm{~m} \mathrm{x}$ $1,6 \mathrm{~m}$, jarak drainase antar plot percobaan yaitu $30 \mathrm{~cm}$ dan jarak drainase antar ulangan yaitu $50 \mathrm{~cm}$.

\section{Penanaman}

Penanaman pada setiap plot percobaan disesuaikan dengan perlakuan varietas. Adapun jarak tanamnya yaitu $60 \mathrm{~cm}$ x $40 \mathrm{~cm}$. Penanaman dilakukan dengan membuat lubang tanam menggunakan tugal. Setiap lubang tanam ditanam sebanyak tiga benih yang nantinya akan dipilih salah satu untuk dibiarkan hidup. 


\section{Pemupukan}

\section{a. Aplikasi Pupuk Anorganik (Pendukung)}

Pupuk anorganik yang direkomendasikan pada budidaya mentimun adalah pupuk SP-36 dan pupuk KCl dengan dosis masing-masing $100 \mathrm{~kg} \mathrm{ha}^{-1}\left(24 \mathrm{~g} \mathrm{plot}^{-1}\right)$ yang diberikan pada saat tanam, dan pupuk urea dengan dosis $180 \mathrm{~kg} \mathrm{ha}^{-1}\left(38,4 \mathrm{~g} \mathrm{plot}^{-1}\right)$ yang diberikan sebanyak dua kali yaitu setengah dosis ketika penanaman dan setengah dosis lagi pada 30 HST. Pemberian pupuk dilakukan dengan sistem larikan.

\section{b. Aplikasi Pupuk Organik Cair (Perlakuan)}

Adapun cara pengaplikasiannya yaitu pupuk organik cair dicampur air sesuai dengan perlakuan yaitu $\mathrm{K}_{0}\left(0 \mathrm{ml} \mathrm{L}{ }^{-1}\right.$ air $), \mathrm{K}_{1}\left(75 \mathrm{ml} \mathrm{L}{ }^{-1}\right.$ air $), \mathrm{K}_{2}\left(150 \mathrm{ml} \mathrm{L}^{-1}\right.$ air $), \mathrm{K}_{3}(225 \mathrm{ml}$ $\mathrm{L}^{-1}$ air), dan $\mathrm{K}_{4}$ (300 ml L $\mathrm{L}^{-1}$ air). Kemudian pupuk organik cair yang telah dicampur dengan air tersebut disiramkan di sekitar perakaran tanaman sebanyak $300 \mathrm{ml}$ di pagi hari pada umur 14, 21 dan 28 HST.

\section{Pemeliharaan}

\section{a. Penyiraman}

Penyiraman dilakukan pada waktu pagi dan sore hari. Namun ketika hujan lebat maka tidak perlu disiram lagi.

\section{b. Penyulaman}

Pada tanaman yang tidak tumbuh dilakukan penyulaman pada hari ke tujuh dengan bibit cadangan yang telah disemai.

\section{c. Pemasangan Ajir}

Pemasangan ajir dilakukan ketika tanaman telah muncul sulur-sulurnya saat tinggi tanaman mencapai sekitar $20 \mathrm{~cm}$.

\section{d. Pengendalian Gulma dan Pembubunan}

Pengendalian gulma dilakukan sebanyak dua kali yaitu ketika tanaman berumur 15 dan 25 HST secara manual yaitu dengan cangkul kecil sekaligus melakukan pembubunan.

\section{e. Pengendalian Hama dan Penyakit Tanaman}

Pengendalian hama pada penelitian ini dilakukan pada umur 10, 17, 25 dan 32 HST menggunakan insektisida Decis 25 EC, karena pada saat itu tanaman terserang kumbang Aulacophora similis Oliver, hama cabuk (kutu putih) dan ulat daun. Sedangkan pengendalian penyakit dilakukan pada umur 7, 10, 13 HST menggunakam fungisida Dithane M-45 $80 \mathrm{WP}$, karena pada saat itu tanaman sangat rentan terhadap penyakit rebah batang (Dumping Off).

\section{Panen}

Buah mentimun pertama kali dipanen pada umur 37 HST. Pemanenan dilakukan dengan interval dua hari sekali sebanyak 5 kali. Pemanenan dilakukan dengan pisau tajam yang digunakan untuk memotong tangkainya supaya lebih mudah dalam mengerjakannya. Adapun kriteria buah yang bisa dipanen yaitu buah yang masih muda namun berukuran besar, dan kulit buahnya halus (duri pada kulit buah sudah hilang).

\section{Parameter yang Diamati.}

\section{a. Tinggi Tanaman $(\mathrm{cm})$}

Tinggi tanaman diamati ketika berumur 24 dan 34 HST pada empat tanaman sampel, dengan cara mengukur panjang batang dari pangkal batang hingga titik tumbuh yang paling tinggi menggunakan tali meteran. 


\section{b. Diameter Batang (mm)}

Diameter batang diamati ketika tanaman berumur 24 dan 34 HST pada empat tanaman sampel, dengan cara mengukur diameter pangkal batang yang berada di permukaan tanah menggunakan jangka sorong.

\section{c. Jumlah Buah Per Tanaman}

Pengamatan jumlah buah per tanaman dilakukan dengan menjumlahkan semua buah pada tanaman sampel dari panen pertama sampai kelima.

\section{d. Diameter Buah (mm)}

Pengukuran diameter buah dilakukan dengan menggunakan jangka sorong pada tiap-tiap buah di bagian tengahnya.

\section{e. Panjang Buah (cm)}

Pengukuran panjang buah dilakukan menggunakan meteran pada tiap-tiap buah dari pangkal hingga ujung buah.

\section{f. Berat Buah per Buah (g)}

Pengamatan berat buah dengan melakukan penimbangan pada tiap-tiap buah memakai timbangan digital.

\section{g. Berat Buah Per Tanaman (kg)}

Pengamatan berat buah per tanaman dilakukan dengan cara menjumlahkan berat semua buah dari panen pertama sampai kelima.

\section{h. Potensi Hasil (ton ha ${ }^{-1}$ )}

Potensi hasil dihitung dengan rumus sebagai berikut :

Potensi hasil $\left(\right.$ ton $\left.\mathrm{ha}^{-1}\right)=\frac{\text { Luas lahan } 1 \mathrm{ha}-20 \%}{\text { Jarak tanam }} \times$ Berat buah per tanaman

\section{HASIL DAN PEMBAHASAN}

\section{Pengaruh Konsentrasi Pupuk Organik Cair Terhadap Pertumbuhan dan Hasil Tanaman Mentimun}

Tabel 1. Rata-rata pertumbuhan dan hasil tanaman mentimun akibat perlakuan konsentrasi pupuk organik cair

\begin{tabular}{lccccc}
\hline \multirow{2}{*}{\multicolumn{1}{c}{ Parameter yang diamati }} & \multicolumn{5}{c}{ Konsentrasi Pupuk Organik Cair } \\
\cline { 2 - 6 } & $0(\mathrm{ml} / \mathrm{L}$ air $)$ \\
& & $75\left(\mathrm{~K}_{1}\right)$ & $150\left(\mathrm{~K}_{2}\right)$ & $225\left(\mathrm{~K}_{3}\right)$ & 300 \\
& & & & $\left(\mathrm{~K}_{4}\right)$ \\
\hline Tinggi tanaman 24 HST (cm) & 24.94 & 31.90 & 26.78 & 31.88 & 35.49 \\
Tinggi tanaman 34 HST (cm) & 109.51 & 134.98 & 119.80 & 132.72 & 135.04 \\
Diameter batang 24 HST (mm) & 5.91 & 6.25 & 6.15 & 6.54 & 6.72 \\
Diameter batang 34 HST (mm) & 8.39 & 8.98 & 8.55 & 8.81 & 8.82 \\
Jumlah buah per tanaman & & 6.50 & 6.38 & 6.46 & 6.46 \\
(buah) & 6.42 & & & & \\
Panjang buah (cm) & 16.36 & 17.49 & 16.59 & 17.19 & 16.97 \\
Diameter buah (mm) & 46.85 & 46.76 & 46.97 & 47.11 & 47.41 \\
Berat buah per buah (g) & 216.72 & 237,34 & 221.89 & 233.01 & 220.62 \\
Berat buah per tanaman (Kg) & 1.39 & 1.55 & 1.40 & 1.42 & 1,43 \\
Potensi hasil (ton/ha) & 46.44 & 51.39 & 46.78 & 47.28 & 47,61 \\
\hline
\end{tabular}


Tabel 1 menunjukkan bahwa rata-rata diameter batang 34 HST, jumlah buah per tanaman, panjang buah, berat per buah, berat buah per tanaman dan potensi hasil cenderung lebih baik dijumpai pada perlakuan pupuk organik cair dengan konsentrasi 75 $\mathrm{ml} / \mathrm{L}$ air $\left(\mathrm{K}_{1}\right)$, sedangkan rata-rata tinggi tanaman 24 dan 34 HST, diameter batang 24 HST dan diameter buah cenderung lebih baik dijumpai pada perlakuan pupuk organik cair dengan konsentrasi $300 \mathrm{ml} / \mathrm{L}$ air $\left(\mathrm{K}_{4}\right)$ meskipun secara statistik tidak berpengaruh nyata

Ada dua dugaan yang menyebabkan konsentrasi pupuk organik cair tersebut tidak berpengaruh pada seluruh parameter yang diamati. Duagaan pertama yaitu konsentrasi pupuk organik cair yang diberikan terlalu rendah sehingga nutrisi yang diperlukan tanaman tidak dapat tercukupi, maka perlu dilakukan peningkatan konsentrasi agar pupuk organik cair dapat mencukupi nutrisi yang diperlukan tanaman sehingga berpengaruh pada pertumbuhan dan hasil.

Peningkatan konsesntrasi pupuk organik cair diduga akan bisa memberi dampak yang lebih besar pada pertumbuhan dan hasil tanaman. Berdasarkan penelitian Afrianto (2014) bahwasanya pupuk organik cair daun lamtoro dengan taraf $500 \mathrm{cc} \mathrm{L}^{-1}$ air menunjukkan hasil yang lebih baik dari taraf $0,100,200,300$ dan $400 \mathrm{cc} \mathrm{L}^{-1}$ air. Dan hasil tersebut berpengaruh sangat nyata pada peubah tinggi tanaman, lingkar batang dan total luas daun bibit kelapa sawit. Kemudian pada penelitian Kelen (2017) pupuk organik cair beberapa jenis kulit buah juga menunjukkan hasil yang berpengaruh sangat nyata pada tanaman sambung nyawa (Gynura procumbens) pada pengamatan tinggi tanaman, diameter tanaman dan jumlah daun. Nilai tertinggi berturut-turut terdapat pada perlakuan pupuk organik cair dengan konsentrasi 30\% (300 ml pupuk organik cair $+700 \mathrm{ml}$ air), konsentrasi 20\% (200 ml pupuk organik cair $+800 \mathrm{ml}$ air), konsentrasi 10\% (100 ml pupuk cair $+900 \mathrm{ml}$ air) dan kontrol dengan nilai terendah.

Dugaan kedua yaitu cara pengaplikasian pupuk organik cair yang tidak tepat karena pada percobaan ini pupuk organik cair disiramkan ke bagian perakaran tanaman sehingga unsur hara tidak dapat langsung diserap oleh tanaman melainkan harus diangkut oleh akar terlebih dahulu dari tanah menuju ke pembuluh xylem kemudian dibawa ke bagian daun. Maka perlu dilakuakan pengaplikasian pupuk organik cair melalui daun supaya unsur hara bisa langsung diserap oleh stomata sehingga jumlah klorofil daun dapat meningkat.

Hanolo (1997) bahwa dari beberapa penelitian yang telah dilakukan bahwasanya pengaplikasian pupuk organik cair melalui daun menunjukkan pertumbuhan dan hasil tanaman yang lebih baik dibanding pengaplikasian melalui tanah. Menurut Siboro et al (2013) penggunaan pupuk organik cair memiliki beberapa kelebihan yaitu memperbaiki kualitas nutrisi, tidak menyebabkan terjadinya pencucian hara, nutrisinya lebih cepat tersedia dan mudah dan mudah terserap tanaman, serta penerapannya mudah karena bisa langsung disemprotkan ke tanaman. Hal tersebut juga sependapat dengan Rizqiani et al (2007) bahwa keunggulan pupuk organik cair adalah dapat disiramkan ke daun sehinga dampaknya akan lebih cepat terlihat. Pada umumnya pupuk organik cair mempunyai komponen nutrisi makro dan mikro cukup lengkap, serta mudah terlarut dalam air sehingga memungkin tanaman untuk menyerapnya dengan lebih cepat. 


\section{Pengaruh Varietas Terhadap Pertumbuhan dan Hasil Tanaman Mentimun}

Tabel 2. Rerata pertumbuhan dan hasil tanaman mentimun akibat perlakuan varietas mentimun

\begin{tabular}{lcc}
\hline \multirow{2}{*}{ Parameter yang diamati } & \multicolumn{2}{c}{ Varietas Mentimun } \\
\cline { 2 - 3 } & Hercules $\left(\mathrm{V}_{1}\right)$ & Mercy $\left(\mathrm{V}_{2}\right)$ \\
\hline Tinggi tanaman 24 HST (cm) & 29.22 & 31.18 \\
Tinggi tanaman 34 HST (cm) & 124.23 & 128.59 \\
Diameter batang 24 HST (mm) & 6.27 & 6.35 \\
Diameter batang 34 HST (mm) & 8.58 & 8.84 \\
Jumlah buah per tanaman (buah) & 6.58 & 6.30 \\
Panjang buah (cm) & $17.80 \mathrm{~b}$ & $16.04 \mathrm{a}$ \\
Diameter buah (mm) & $46.13 \mathrm{a}$ & $47.92 \mathrm{~b}$ \\
Berat buah per buah (g) & $232.44 \mathrm{~b}$ & $219.39 \mathrm{a}$ \\
Berat buah per tanaman (Kg) & 1.52 & 1.36 \\
Potensi hasil (ton/ha) & 50.56 & 45.24 \\
\hline
\end{tabular}

Keterangan : Angka yang diikuti oleh huruf yang sama pada baris yang sama menunjukkan berbeda tidak nyata pada uji DNMRT $(\alpha=0,05)$.

Tabel 2 menunjukkan bahwa rata-rata panjang buah dan berat buah per buah terbaik dijumpai pada varietas Hercules yang berbeda nyata dengan varietas Mercy. Ratarata diameter buah terbaik dijumpai pada varietas Mercy yang berbeda nyata dengan varietas Hercules. Rata-rata tinggi tanaman dan diameter batang umur 24 dan 34 HST cenderung lebih baik dijumpai pada varietas Mercy, sedangkan rata-rata jumlah buah per tanaman, berat buah per tanaman dan potensi hasil cenderung lebih baik dijumpai pada varietas Hercules meskipun secara statistik tidak berpengaruh nyata. Hasil tersebut sejalan dengan penelitian yang telah dilakukan oleh Ginting (2010) yang menunjukkan bahwa varietas Hercules $\left(\mathrm{V}_{1}\right)$ menghasilkan buah yang terpanjang yaitu $24,34 \mathrm{~cm}$ yang berbeda nyata dengan varietas Mercy $\left(\mathrm{V}_{2}\right)$ dan varietas Lokal $\left(\mathrm{V}_{3}\right)$ dengan nilai berturutturut 22,06 dan 19,90 cm. Kemudian varietas Hercules $\left(\mathrm{V}_{1}\right)$ juga menghasilkan berat buah per tanaman yang lebih tinggi yaitu sebanyak 310,10 g dibandingkan dengan varietas Mercy $\left(\mathrm{V}_{2}\right)$ yang hanya sebanyak 304,67 g, sedangkan yang tertinggi adalah varieatas Lokal $\left(\mathrm{V}_{3}\right)$ yaitu sebanyak 339,86 g.

Setiap varietas memiliki keunggulan masing-masing, varietas Mercy menghasilkan diameter buah lebih besar namun tidak begitu panjang, sedangkan varietas Hercules menghasilkan buah lebih panjang dan berat namun diameter buah tidak begitu besar. Perbedaan hasil yang ditunjukkan oleh varietas Hercules $\left(\mathrm{V}_{1}\right)$ dan varietas Mercy $\left(\mathrm{V}_{2}\right)$ diduga adanya pengaruh genetik dari masing-masing varietas tersebut. Menurut Syarif et al (2010) bahwa setiap varietas akan memperoleh hasil panen serta sifat buah yang berbedabeda, hal tersebut karena perbadaan genetic yang dimilikinya. Adapun perbedaan sifat genetik tersebut mengakibatkan tanaman memberikan respon berbeda-beda pada lingkungan. Pernyataan tersebut sependapat dengan Sitompul dan Guritno (1995), bentuk tanaman ada dalam kendali sifat genetik namun dipengaruhi faktor-faktor lingkungan. Perbedaan pada susunan genetic adalah salah satu faktor yang mengakibatkan keragaman bentuk tanaman.

Berdasarkan deskripsi dijelaskan bahwa varietas Hercules memiliki panjang buah mencapai $\pm 18,6 \mathrm{~cm}$ (PT. BISI Internasional Tbk) dan varietas Mercy memeliki panjang 
buah $\pm 22-24 \mathrm{~cm}$ (PT. East-West Seed). Namun pada kenyataanya varietas Hercules menghasilkan buah yang lebih panjang dibandingkan dengan varietas Mercy. Hal tersebut diperkirakan karena varietas Mercy tidak dapat beradaptasi dengan lingkungan sehingga memperoleh hasil yang kurang maksimal, sementara itu varietas Hercules dapat beradaptasi dengan lingkungan sehingga memperoleh hasil seperti yang diinginkan.

Menurut Adisarwanto (2006) kemampuan varietas yang unggul masih dipengaruhi adanya interaksi antara genetik dan kondisi pengolahan lingkungan. Jika pengolahan lingkungan tidak dilakukan dengan benar, maka kemampuan berproduksi tinggi dari varietas unggul tersebut tidak bisa terwujud. Sudadi (2003) mengemukakan bahwa selain unsur genetic ternyata kondisi alam berpengaruh pula pada proses tumbuh dan produksi tanaman. Sutapradja (2008) juga berpendapat bahwa selain dari faktor genetik, faktor lingkungan, teknik pengolahan, dan kualitas benih juga mempengaruhi produksi mentimun.

\section{Pengaruh Interaksi Konsentrasi Pupuk Organik Cair dengan Varietas Mentimun}

Tabel 3. Rerata panjang buah akibat interaksi antara konsentrasi pupuk organik cair dengan varietas mentimun

\begin{tabular}{ccc}
\hline \multirow{2}{*}{$\begin{array}{c}\text { Konsentrasi Pupuk Organik Cair } \\
\text { (ml/L air) }\end{array}$} & \multicolumn{2}{c}{ Varietas Mentimun } \\
\cline { 2 - 3 } $0\left(\mathrm{~K}_{0}\right)$ & $17,51 \mathrm{~cd}$ & Mercy $\left(\mathrm{V}_{2}\right)$ \\
$75\left(\mathrm{~K}_{1}\right)$ & $18,03 \mathrm{~d}$ & $15,22 \mathrm{ab}$ \\
$150\left(\mathrm{~K}_{2}\right)$ & $18,26 \mathrm{~d}$ & $16,94 \mathrm{bcd}$ \\
$225\left(\mathrm{~K}_{3}\right)$ & $16,94 \mathrm{ad}$ & $14,92 \mathrm{a}$ \\
$300\left(\mathrm{~K}_{4}\right)$ & $18,26 \mathrm{~d}$ & $17,44 \mathrm{~cd}$ \\
\end{tabular}

Keterangan: Angka yang diikuti oleh huruf yang sama pada kolom dan baris yang sama menunjukkan berbeda tidak nyata pada uji DNMRT $(\alpha=0,05)$

Tabel 3 menunjukkan bahwa akibat perlakuan varietas Hercules $\left(\mathrm{V}_{1}\right)$ ) panjang buah dengan nilai yang paling baik terdapat di perlakuan pupuk organik cair berkonsentrasi $150 \mathrm{ml} / \mathrm{L}$ air $\left(\mathrm{K}_{2}\right)$ yang tidak berbeda nyata dengan perlakuan konsentrasi yang lain. Sedangkan akibat perlakuan varietas Mercy $\left(\mathrm{V}_{2}\right)$ panjang buah yang paling baik diperoleh dari perlakuan pupuk organik cair berkonsentrasi $225 \mathrm{ml} / \mathrm{L}$ air $\left(\mathrm{K}_{3}\right)$ yang berbeda nyata dengan $0 \mathrm{ml} / \mathrm{L}$ air $\left(\mathrm{K}_{0}\right)$ dan $150 \mathrm{ml} / \mathrm{L}$ air $\left(\mathrm{K}_{2}\right)$, tetapi tidak berbeda nyata dengan $75 \mathrm{ml} / \mathrm{L}$ air $\left(\mathrm{K}_{1}\right)$ dan $300 \mathrm{ml} / \mathrm{L}$ air $\left(\mathrm{K}_{4}\right)$.

Varietas Hercules $\left(\mathrm{V}_{1}\right)$ paling efisiensi dikombinasikan dengan pupuk organik cair berkonsentrasi $0 \mathrm{ml} / \mathrm{L}$ air $\left(\mathrm{K}_{0}\right)$ karena memperoleh panjang buah yang tidak berbeda nyata dengan konsentrasi lainnya. Sedangkan untuk varietas Mercy $\left(\mathrm{V}_{2}\right)$ paling efektif dikombinasikan dengan pupuk organik cair berkonsentrasi $225 \mathrm{ml} / \mathrm{L}$ air $\left(\mathrm{K}_{3}\right)$ karena memperoleh panjang buah terbaik yang berbeda nyata dengan pupuk organik cair berkonsentrasi $0 \mathrm{ml} / \mathrm{L}$ air $\left(\mathrm{K}_{0}\right)$ dan $150 \mathrm{ml} / \mathrm{L}$ air $\left(\mathrm{K}_{2}\right)$, hal ini diduga konsentrasi tersebut telah mampu memenuhi kebutuhan hara sehingga dapat meningkatkan panjang buah mentimun varietas Mercy $\left(\mathrm{V}_{2}\right)$. Lingga dan Marsono (2008) memaparkan bahwa pengaplikasian pupuk organik cair yang cukup bisa meningkatkan bahan serap terhadap air, memperbaiki struktur tanah, mendukung kehidupan mikroorganisme dalam tanah serta sebagai penyuplai hara bagi tanaman. Pernyataan tersebut sependapat Kurniadi et al (2011) bahwa adanya zat nutrisi yang terserap tanaman adalah salah satu penyebab yang bisa 
berpengaruh pada pertumbuhan tanaman. Komponen nutrisi yang ada harus dalam keadaan yang mencukupi dan berimbang sehingga sehingga proses pertumbuhan tanaman baik.

Setiap varietas mentimun memiliki kapasitas yang berbeda terhadap kebutuhan unsur hara yang diperlukan karena berbeda varietas maka berbeda pula susunan genetiknya. Hal tersebut sesuai dengan pendapat Sumaryo (1995), bahwa tiap-tiap varietas mempunyai genotip berbeda sehingga menyebabkan penampakan dari fenotipe tanaman itu juga berbeda jika lingkungan mendukung. Menurut Adisarwanto (2006) kemampuan varietas yang unggul masih dipengaruhi adanya interaksi antara genetik dan kondisi pengolahan lingkungan. Jika pengolahan lingkungan tidak dilakukan dengan benar, maka kemampuan berproduksi tinggi dari varietas unggul tersebut tidak bisa terwujud. Faktor internal yang dapat merangsang pertumbuhan tanaman dikendalikan oleh genetik, namun unsur-unsur lain seperti iklim, tanah, hama, penyakit, gulma dan persaingan untuk memperebutkan zat hara juga bisa berpengaruh terhadap pertumbuhan dan produksinya (Gardner et al, 1991).

\section{SIMPULAN}

Perlakuan konsentrasi pupuk organik cair memperoleh pengaruh yang tak nyata pada seluruh parameter pengamatan. Perlakuan varietas memberikan pengaruh yang sangat nyata pada panjang dan diameter buah serta berpengaruh nyata terhadap berat buah per buah. Panjang buah dan berat buah per buah terbaik terdapat pada varietas Hercules $\left(\mathrm{V}_{1}\right)$, sedangkan diameter buah terbaik terdapat pada varietas Mercy $\left(\mathrm{V}_{2}\right)$. Interaksi varietas Hercules $\left(\mathrm{V}_{1}\right)$ paling efisiensi dikombinasikan dengan konsentrasi pupuk organik cair 0 $\mathrm{ml} / \mathrm{L}$ air $\left(\mathrm{K}_{0}\right)$ Sedangkan pada varietas $\operatorname{Mercy}\left(\mathrm{V}_{2}\right)$ paling efektif dikombinasikan dengan konsentrasi pupuk organik cair $225 \mathrm{ml} \mathrm{L}^{-1}$ air $\left(\mathrm{K}_{3}\right)$.

\section{DAFTAR PUSTAKA}

Adisarwanto, T. 2006. Budidaya dengan Pemupukan yang Efektif dan Pengoptimalan Peran Bintil Akar Kedelai.Penebar Swadaya. Jakarta.

Badan Pusat Statistik. 2017. Tanaman Hortikultura : Tabel Hasil Produksi Tanaman Ketimun Indonesia . https://www.bps.go.id/site/resultTab. Diakses pada tanggal 14 Maret 2019.

Badan Pusat Statistik. 2019. Statistik Tanaman Sayuran dan Buah. https://www.bps.go.id/p ublication/2019/10/07/9c5dede09c805bc38302ea1c/statistik-tanaman-sayuran-danbuah---buahan-semusim-indonesia-2018.html. Diakses pada tanggal 25 April 2019.

Dermiyati., S. D. Utomo., K. F. Hidayat., J. Lumbanraja., S. Triyono., H. Ismono., N. E. Ratna., N.T. Putri., dan R. Taisa. 2015. Pengujian pupuk organonitrofos plus pada jagung manis (Zea mays saccharata L.) dan perubahan sifat kimia tanah Ultisol. J. Trop. Soils 21 (1) : 9-17. DOI: 10.5400/jts.2016.21.1.

Duaja, W. 2012. Pengaruh pupuk urea, pupuk organik padat dan cair kotoran ayam terhadap sifat tanah, pertumbuhan dan hasil selada keriting di tanah inceptisol. Jurnal Agroteknologi Cendana 1(4) : 236-246.

Gardner, F.P., R. B. Pearce dan R. I. Mitchell. 1991. Fisiologi Tanaman Budidaya. Universitas Indonesia press, Jakarta.

Hanolo, W.1997. Tanggapan Tanaman Selada dan Sawi terhadap dosis dan cara pemberian pupuk cair stimulant. Jurnal Agrotropika, 1: 25-29. 
Idris, M. 2004. Respon tanaman mentimun (Cucumis sativus L.) akibat pemangkasan dan pemberian pupuk ZA. Jurnal Penelitian Bidang Ilmu Pertanian. 2 (1) : 17-24.

Kelen, P. A. 2017. Pengaruh konsentrasi pupuk cair campuran dari beberapa kulit buah terhadap pertumbuhan sambung nyawa (Gynura procumbens Lour.) Merr. Skripsi. Program Studi Biologi Fakultas Teknobiologi Universitas Atma Jaya Yogyakarta.

Kurniadi, P.F., H. Yetti dan E. Anom. 2011, Peningkatan Produksi Kacang Hijau (Vigna radiata L.) Dengan Pemberian Pupuk Kandang Ayam dan NPK. Skripsi. Jurusan Budidaya Pertanian Fakultas Pertanian Universitas Riau, Riau.

Pardosi, A. H., Irianto dan Mukhsin. 2014. Respons Tanaman Sawi terhadap Pupuk Organik Cair Limbah Sayuran pada Lahan Kering Ultisol. Jambi: Universitas Jambi. Prosiding Seminar Nasional Lahan Suboptimal 2014, Palembang 26-27 September 2014 ISBN : 979-587-529-9.

Rizqiani, N.F., E. Ambarwati., N.W. Yuwono. 2007. Pengaruh dosis dan frekuensi pemberian pupuk organik cair terhadap pertumbuhan dan hasil buncis (Phaseolus vulgaris L.) dataran rendah. Jurnal Ilmu Tanah dan Lingkungan, 7(1) : 43-53.

Rostini, T., G. K. Ni'mah, dan S. Sosilawati. 2016. Pengaruh pemberian pupuk bokashi yang berbeda terhadap kandungan protein dan serat kasar rumput gajah (Pennisetum purpureum). Ziraa'ah Majalah Ilmiah Pertanian, 41(1): 118-126.

Rukmana, R. 1994. Budidya Mentimun. Kanisius, Yogyakarta.

Siboro, E.S., E. Surya dan N. Herlina 2013. Pembuatan pupuk cair dan biogas dari campuran limbah sayuran. Jurnal Teknik Kimia USU, 2 (3): 40-43.

Sudadi. 2003. Kajian pemberian air dan mulsa terhadap iklim mikro pada tanaman cabai di tanah ultisol. Jurnal Ilmu Tanah dan Lingkungan. 4:(1):41-49.

Sumaryo, P. 1995. Pemuliaan Tanaman. PAU IPB, Bogor. 